\title{
Reconciling Complexity Theory in Organizations and Christian Spirituality
}

\author{
by Eric B. Dent
}

This article originally appeared in Emergence: Complexity and Organization 5.4 (2003)

The lenses of complexity theory have been trained on a variety of subjects in organizations, ranging from assembly lines to strategic planning. While this work has been going on, another group of researchers has been actively pursuing the study of workplace spirituality. The latter body of work has resulted in the formation of the Management, Spirituality, and Religion interest group of the Academy of Management in 2000, the creation of journals of workplace spirituality (including the Journal of Management, Spirituality, and Religion), and a steady stream of special issues on the topic (calls in 2003 alone included "Theological Perspectives on Accounting," Accounting, Auditing and Accountability Journal; "Research Issues and Research Findings in Spirituality in Organizations," Journal of Organizational Change Management; and "Spiritual Leadership," Leadership Quarterly).

No work has been published that endeavors to interrelate complexity theory with workplace spirituality, however. In fact, a striking feature of the complexity theory literature is an absence of consideration of spiritual dimensions or wisdom traditions. Complexity theory books and articles that reference the deep implications of the work subtly or overtly further the scientific tradition of negating religious traditions by alleging that these scientific findings provide additional evidence that certain religious traditions are not valid. Although the interpretations of these scientific findings have different manifestations (such as denying a spiritual dimension to life or denying creation by intelligent design), at their essence they are all a denial of the existence of God. (1) Well-read sources with this orientation include Waldrop (2) (1992), Kaufman (1995), Stewart and Cohen (1996), and Gould (1999). Those researchers did not see God's hand in the interpretation of the data. Looking at the same evidence, however, I will suggest that many complexity theory philosophies and evidence strengthen, rather than weaken, the case for the existence of a supreme being and the religious traditions associated with such a belief.

It will be argued here that new organization theories based on complexity theory should be consistent, rather than at odds, with religious traditions. Although much of the case made in this article is congruent with multiple other religious traditions, the focus here is on Christianity and some examples are uniquely Christian. In Dent (forthcoming3), I make the case for the existence of God using solely humanistic sources. Sources for this argument include Godel's Incompleteness Theorem, which proves that rational thought can never reach the ultimate truth; Heisenberg's (1962) proof arguments of the philosophy of science, which demonstrate that no one can observe nature directly, only nature exposed to a method of questioning, and that each method of questioning is limited; and recent brain research (Newberg et al., 2001: 9) demonstrating

[the] brain's capacity to make spiritual experience real ... [There is now] evidence of a neurological process that has evolved to allow us humans to transcend material existence and acknowledge and connect with a deeper, more spiritual 
part of ourselves perceived of as an absolute, universal reality that connects us to all that is.

Other proofs of the existence of God, which will not be presented in detail here, have ranged from philosophy to biology to psychiatry to management. Centuries ago, St. Thomas, although a Christian, offered five proofs for the existence of God from a naturalist and philosophical standpoint, rather than a religious one. These range from the proof from efficient cause to the teleological proof. To choose one for illustration, Thomas's proof from "necessary being" contends that if something exists now, there must have always been something in existence. Consequently, something must have necessary being. This being is both logically and ontologically necessary and can be called God.

Evidence for the existence of God from a biological standpoint includes the Commission on Children at Risk's 2003 Report, "Hardwired to Connect: The New Scientific Case for Authoritative Communities," jointly sponsored by the YMCA of the USA, Dartmouth Medical School, and the nonpartisan Institute for American Values. This report presents findings such as that humans have a biological drive to be connected to the transcendent and to strive for moral and spiritual meaning in the same way that people have a biological sex drive (Boisture, 2003).

One of the more recent and fascinating proofs of the existence of God is found in Sandelands (2003). He demonstrates that God can be justified solely on the basis of how business corporations are structured and function. Sandelands develops his case from three perspectives, the argument from management, the argument from organization, and the argument from social life. He points out that in spite of human failings and the occasional books on winning by intimidation or swimming with sharks, by and large normative organizational practice includes principled negotiation, work design for satisfying and ennobling work, and so forth. Each of these practices is grounded in the notion of a God before whom "all people are equal, all people share in a fundamental dignity, and all people are loved" (Sandelands, 2003: 170).

Sandelands' argument from organization follows the pattern of this article. He illustrates how taking the work of the atheist Sigmund Freud to its logical conclusion results in God. Freud contended that the psyche of humans is such that we need a father figure to bring us to truth and to rescue us from our human anxiety. Freud also showed that there must be a father figure beyond logical reason and human existence who can perform these functions for us. This figure is commonly called God. Sandelands' third argument will not be elaborated here.

Although newer additional evidence for the existence of God is surfacing, at the same time scientists' claims to have made discoveries that refute teachings of the religious and wisdom traditions persist and are not new to the scene. Such activity has been going on for hundreds of years. In recent years, though, a number of scholars and researchers have endeavored to bridge the gap between science and religion. Books such as The Marriage of Sense and Soul (Wilber, 1998) and the activities of over 150 groups such as The Center for Theology and the Natural Sciences are considering the integration of science and religion. These efforts typically take the form of taking a common core of science and its methods that is acceptable to the religious traditions and finding a common core of religion that is in accordance with scientific practice. If complexity theory is to be consistent with attempts to integrate science and religion, it must not fall into the "traps" that some argue are simply bad science, and others note are inconsistent with 
religious traditions. Science has a wonderful history of illuminating unseen and unheard phenomena, ranging from electromagnetic fields to ultrahigh frequency sound waves to the inside of an atom. At the same time, one of the overreaches by science is acceptance of the philosophy of scientific materialism, the "conception of the universe as composed basically of matter (or matter/energy) ... best studied by science, and science alone" (Wilber, 1998: 10).

As with the evolution of any new discipline, at this stage of development there is no single complexity "science" and work in complexity theory varies in the degree to which it ascribes to scientific materialism. In general, though, complexity theory has been shown to make the assumptions of what can be called an emerging worldview (EWV) as opposed to a traditional worldview (TWV) that includes scientific materialism (Dent, 1999). The worldviews comprise different viewpoints on a variety of polarities (see discussion of polarities below) that include equality/patriarchy, mutual causation/direct causation, understanding/prediction and many others.

\section{EWV}

Holism/reductionism

Perspectival/objective observation

Paradox (polarity)/logic

Indeterminism (free will)/Determinism
TWV

Reductionism

Objective observation

Logic

Determinism

The EWV is itself the recognition that philosophical assumptions often form a polarity so that both ends of the pole are useful in a variety of situations. The discussion here will be limited to four representative dimensions of worldview in organizations. The first two dimensions have been shown to be among the three primary determinants of worldview in organizations (Dent, 1999). The choice of these four allows for illustration primarily from natural sciences in two cases and primarily from social sciences in the other two.

In general, then, recent work in complexity theory supports the philosophical assumptions of the EWV. When those interpreters use the findings to challenge religion, they make the premise that religion holds TWV philosophical assumptions. In fact, as this article will show, the EWV assumptions are very consistent with Christianity. Each of the four sections that follow will introduce the philosophical dilemmas manifested in organizational challenges, explicate some recent work in complexity theory, and provide evidence from religious sources that demonstrates consistency with that work. The contention of this article is that the illustrations here, though limited, are representative of the religious philosophy as a whole.

\section{PARADOX (POLARITY)/LOGIC}

Organizational leaders are perpetually faced with a series of questions. In this major change effort I want to initiate, can the change be driven from the top down or must it be self-organizing at the grassroots level? How do I make sure my organization is constantly innovating and at the same time delivering a standardized level of service? How do I encourage my top management group to work as a team and at the same time not lose my star performers? Paradoxes arise "when a set of individually plausible propositions is collectively inconsistent" (Rescher, 2001: 6 ). The terminology in the literature is not yet consistent. Sometimes the same phenomenon is 
described as a polarity (Johnson, 1992) or a dilemma. Paradoxes can be classified into categories such as rhetorical, logical, and communicative. What the three questions above all have in common is that they represent logical paradoxes. Yet, one of the bedrock principles of science is the universal applicability of logic. Recently, though, a number of organizational scholars have suggested that an understanding of and facility with paradoxes are as important, if not more important, than understanding logic.

Complexity theory suggests that paradoxes should not be seen as implausible. Rather, they "create a tension from which creative solutions emerge" (Regine \& Lewin, 2000: 19). This realization can shake someone at the core of their being. Charles Handy (1994: xi), for example, writes,

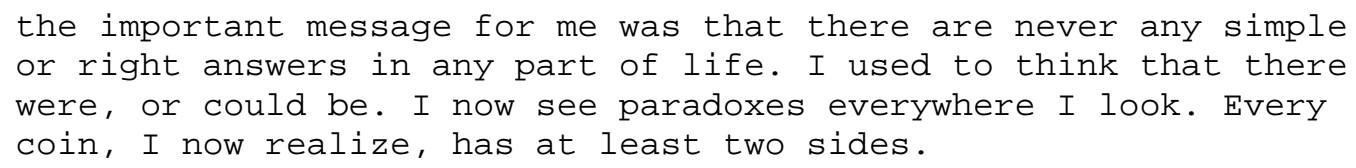

Others see the concept of paradox as so important that they now define leadership as essentially the management of paradoxes (Farson, 1996; Lewin \& Regine, 2000).

Although leadership is defined above as the management of paradoxes, paradoxes are not managed in the way that problems are. Paradoxes have to be constantly managed, for they are never "solved" like problems. Handy's (1994: 12) words are again instructive on this point:

I used to think that paradoxes were the visible signs of an imperfect world ... Paradox I now see to be inevitable, endemic, and perpetual.

Perhaps surprisingly, some see the role of paradox as critical to concepts such as integrity. Peck (1987: 238) asserts,

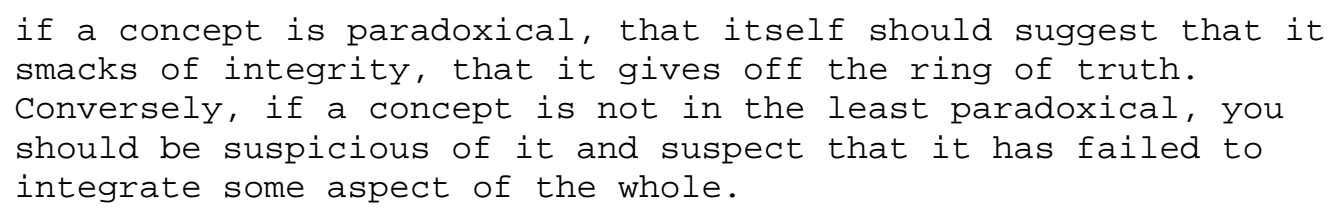

Handy (1994) has identified nine principal paradoxes that he feels are critical for anyone wanting to understand societies or organizations. These range from the Paradox of Intelligence to the Paradox of the Individual. Farson (1996) identifies as most significant an understanding of the paradoxes of human relations, communication, the politics of management, organizational predicaments, change, and leadership. In the paradox of human relations, for example, research suggests that once managers find a technique that works, they must abandon it in order to maintain effectiveness.

Paradox has been at the core of eastern religious traditions for millennia. Also, Franck in 1534 published a collection of 280 paradoxes found in the Bible. It is the judgment of those both decidedly not Christian (Bateson \& Bateson, 1987: 146) and those Christian (Peck, 1993b: 21 
(4)) that Christianity as a religious system is more consistent than the world's other great religions in its paradoxical structure.

Paradoxes abound in Christianity. Jesus is both human and divine,

and not simply fifty percent one and fifty percent the other.

Paradox does not divide into categories but transcends categories

through a mystery that may never be fully comprehensible and yet

is often more real than the purely logical. (Peck, 1987: 242)

A second example of a paradox in Christian faith is the claim that only by totally surrendering self are people completely free (John 8:31b-32 "If you obey my teaching, you are really my disciples; you will know the truth, and the truth shall set you free"). Also,

humans are made in God's image and therefore have the potential

for enormous good, yet as fallen beings they are also selfish

and rebellious toward God (Daniels et al., 2000: 553)

A final example offered here is that God is both in heaven (Matthew 6:9 "Our Father in heaven, hallowed be your name") and in human hearts (1 John 4:12b-13 "If we love one another, God lives in us and his love is made complete in us. We know that we live in him and he in us, because he has given us of his Spirit").

Ironically, the cultural hegemony of scientific logic has caused Christians to shy away from the blatant paradoxes in scripture. A greater understanding and appreciation of paradox has the potential to enhance spiritual development as well as improve organizational practice.

\section{HOLISM/REDUCTIONISM}

As a leader in an organization, how do I establish an organizational structure that adequately addresses the fullness of the mission in a changing, white-water context? How do I measure the performance of a top manager when I think she did a great job but doesn't have the bottom line to prove it because of bad luck or circumstances beyond her control? If I benchmark the industry leader, how do I account for the role of values and culture in its success? Each of these questions is intractable for people thinking reductionistically. Proponents of quantitative organizational methods and scientific materialism are wedded to the assumption of reductionism. (5)

Simply put, from that viewpoint, the whole is equal to the sum of its parts. Until the past few hundred years, science, philosophy, and religion all subscribed to the theory that there are levels of being starting with inert matter, and passing through organic matter, nonhuman life forms, and then within people--body, mind, and soul. Scientists have argued that all of the higher levels can be reduced to matter. The soul, for example, is presently described as a series of brain functions that are not yet fully understood. Wilber (1996: 19) has critiqued this argument by noting that

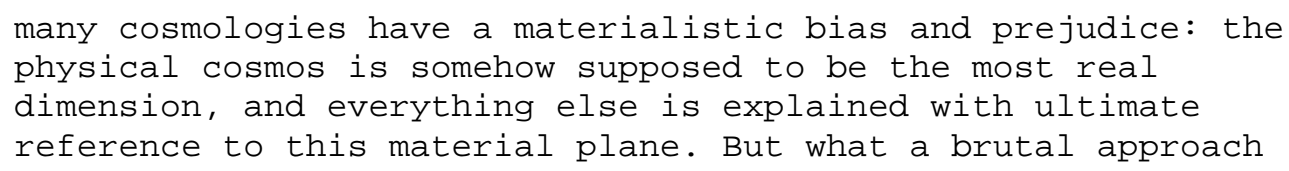


that is! It smashes the entire Kosmos against the wall of reductionism, and all of the domains except the physical slowly bleed to death right in front of your eyes.

Science has proceeded almost exclusively by using methods that are empirical and objectifying, revealing the exteriors and surfaces of phenomena. This approach allows for far greater understanding of a sailfish on a dissector's table than it does for one swimming in the wild. In organization theory, the reductionist method is to use the organization chart as a framework for study rather than process flow charts, for example. Leadership, too, is simply the accumulation of attributes and functions such as intellectual stimulation, individualized consideration, planning, and delegating rather than a holistic phenomenon including values, determination, motives, and other ways of being. Occasionally, though, the information most needed is discovered by reduction. However, a far greater number of phenomena of primary interest are essentially inaccessible by these methods. These questions include: What is leadership or spirituality? How do we know for sure whether a customer will maintain allegiance with one company? Will the new formula for a soda be a flop or a hit?

Wilber (1996: 87) suggests that these questions require study of interior dimensions that

can only be accessed by communication and interpretation, by

"dialogue" and "dialogical" approaches, which are not staring

at exteriors but sharing of interiors. Not objective but

intersubjective. Not surfaces but depths.

Another important factor is the inclusion of context. Bateson's (1979) work suggests that animals (and graduate students) studied in experimental settings are cued to the "I'm being studied" stimulus by the details of the lab, which may include its smell, the experimental stand on which the animal is supported, and so forth. Consequently, findings that were confirmed in an animal study in the lab were not substantiated when the same studies were conducted with the animal in its natural context. Any change in context can introduce a variable that alters the findings.

Perhaps the work in physics is causing the most rapid decline in reductionist thinking and inspiring holistic organizational researchers. Atomic physicists now believe that particles within the atom are not independently existing, analyzable entities. Prevailing research in elementary physics works under the assumption that subatomic study is of a set of interactions and relationships, not of things (Gell-Mann, 1994). This view is captured in Bell's Theorem: No theory of reality compatible with quantum theory can require spatially separated events to be independent (Schwartz \& Ogilvy, 1979: 33). These discoveries provoke the possibility of relationship being the central concept of organizational life. Other work in cybernetics includes the development of a proof that a focus on optimizing each of the parts results in the suboptimization of the whole. This proof has implications for TQM, reengineering, and other organizational optimization methods.

Scientists making the EWV assumption of holism are philosophically in sync with Biblical scriptures. That Christianity affirms a spiritual level and a human soul does not need to be belabored here. Jesus Christ's earthly ministry was a daily lesson in holism. In nearly every challenge that Jesus receives from the Pharisees or others, he points out that the question or challenge contains an inappropriate reduction. For example, in the Parable of the Good 
Samaritan (Luke 10), when asked "who is my neighbor?" Jesus redefines the concept of "neighbor" to include anyone seen in need. In Matthew 19, Jesus is confronted by the rich young man who asks for a list of what it takes to receive eternal life. Jesus's response is that eternal life is not achieved via checklists, but by a holistic commitment and attitude change. In fact, theologians would probably not quarrel with the suggestion that a major function of Christ's earthly ministry was to restore the wholeness of life that had been reduced legalistically by the scribes and Pharisees.

Holism and reductionism form a polarity. In the past couple of hundred years, western society has emphasized reductionism. At work it has been manifested by assembly lines and an organization-chart mindset. In religion it is manifested by ritualistic form over function. Recognizing holism as an equal partner in the polarity will make both organizational and religious practice (restored to the guidance of scripture) healthier and more productive.

\section{INDETERMINISM (FREE WILL)/DETERMINISM}

Why is it that the same leadership style used in the same situation often results in different outcomes? How do I maintain a sense of control over my organization knowing that people work best when they are given some autonomy? Deming (1986) has described the most important information I need as unknowable--what should I do now? Determinism is the philosophical assumption of classical science. More recently, though, Ilya Prigogine was awarded a Nobel prize for showing the existence of indeterministic events in chemical reactions. Prigogine and Stengers (1984: xxiii) now see determinism and indeterminism not as irreconcilable opposites but "each playing its role as a partner in destiny."

Human beings take for granted a world of three spatial dimensions and one time dimension (for a total of four). Early in the twentieth century, though, Albert Einstein concluded from his scientific work that there must be additional dimensions. The only other extant document at the time to refer to additional dimensions was the Bible, which had been written thousands of years earlier (Ross, 1996: 21).

Einstein's conclusion was contrary to the generally held belief of the day that the universe is eternal and that time is reversible. George Ellis, Stephen Hawking, and Roger Penrose offered a proof of Einstein's theory in 1966. In 1993, the Nobel prize in physics went to Russell Hulse and Joseph Taylor, who established beyond a shadow of scientific doubt that Einstein was right and that whoever or whatever caused the universe must possess at least one more dimension of time than the one in our universe (Taylor et al., 1992; Penrose, 1994). Even more recent work has suggested that at 10-43 seconds after the creation event began at least 10 dimensions existed, and they split into two pieces: a four-dimension piece that became our dimensions of length, width, height, and time, and a six-or-more-dimension piece that permanently ceased expanding and never produced matter (Green \& Schwarz, 1984). These six or more dimensions remain curled up everywhere within the other four dimensions.

The discovery of these additional dimensions provides a glimpse of an answer to the age-old question of whether human beings have free will or whether God predestined everything that happens. It is possible that both are true. Scientists have shown that if three time dimensions are 
operative, God could predetermine every action of every human being while still sustaining the operation of human choice. As an individual expresses their free will, God can also express his will in sufficient degree to keep his "plan" intact (Peacocke, 1995).

To get an inkling of how God might work in additional spatial dimensions, it is helpful to compare the human situation with one that is more restrictive. Consider a "world" of two spatial dimensions and one time dimension. "Flat people" living in two spatial dimensions would have no clue what three spatial dimensions are like. They could not fathom it. In the same way, humans cannot really fathom four spatial dimensions. If you want to try, think about turning a basketball inside out without making a break in any of the surfaces. In four dimensions, this task is easily accomplished. The Bible tells of Jesus using an extra spatial dimension to enter a room after his crucifixion without opening the locked doors and windows of the disciples' hideout (John 20:19). Imagine how easily people can create the same effect for flat people. If you were to poke your finger in and out of the flat plane, flat people would see a circle appear, then disappear, then reappear in a way that they could not explain. Although people have a difficult time picturing four spatial dimensions, in mathematics additional dimensions are used routinely. A simple equation such as $3 \mathrm{x}+2 \mathrm{y}+\mathrm{z}+4 \mathrm{w}=17$ cannot be illustrated graphically. Organizational researchers using statistical tools such as multivariate regression equations regularly employ additional dimensions.

The work of Einstein, Prigogine, Taylor, Hulse, Penrose, and other scientists squares very nicely with Biblical teachings. On the question of free will and determinism, over 120 scriptural passages speak to either human free will or predestination by God, sometimes in the same passage (Ross, 1996: 136). For example, Ephesians 1:11-13,

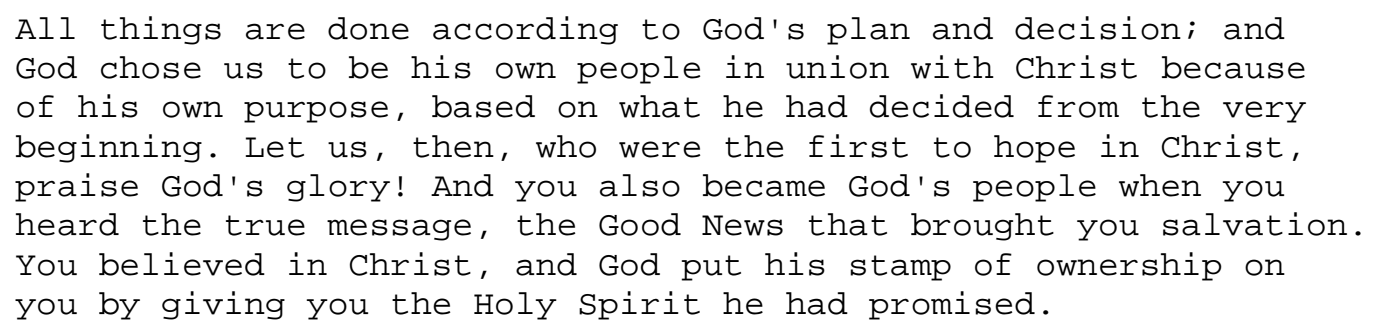

Christianity teaches, then, that the managerial questions at the beginning of this section cannot be answered with certainty. From a human, four-dimensional perspective, the world is probabilistic and uncertain. Although some risks can be mitigated, the notion of control is paradoxical, as discussed above.

\section{PERSPECTIVAL OBSERVATION/OBJECTIVE OBSERVATION}

How do I help resolve a conflict between two subordinates when their sides of the story sound equally right (and/or wrong)? How do we design the perfect product for a stay-at-home mother when no one who works here has that viewpoint? Why do people think of me as arrogant when I never feel as though I'm being arrogant? Perspectival observation is a term that means that phenomena or information in the world are dependent, to some extent, on the method of observation, and that the definition of an appropriate perspective may change depending on what information is requested. Moreover, the phenomena or information may be changed by the act of 
observing. Some suggest that truth is subjective or relative. Although perspectival observation suggests that most phenomena are interpreted or mediated, and that the interpretation may differ, it does not preclude the existence of an absolute truth. Certainly, religion asserts some absolute truths. At the same time, variation in Christian denominations, even those considered part of the orthodoxy, witnesses to the perspectival interpretation that helps to keep a historical document timeless in its application. The scriptures themselves assert the importance of perspective, suggesting that it is best to have two or more witnesses to a claim (Matthew 18:16). Moreover, Christ's predominant teaching method, the parable, is an inherently perspectival approach.

As with the reinterpretation of paradox (above), the ascendance of belief in perspectival observation means that aspects of the Bible that were formerly criticized are now in vogue with current thinking. For example, the story of Jesus's earthly ministry is told in four different books. According to the TWV, this is problematic because if reality is objective, there should be only one true story. The approach of some scholars to discrediting the Bible is to point out that in Luke it says that three women went to the tomb (Luke 24:10) and found the stone rolled away, but in John it says only one woman (John 20:1). Complexity theory recognizes that if four people tell the same story it will be told in four different ways with different emphases, purposes, and details.

Traditional organizational research has also been critiqued for another feature that has been at odds with Biblical teaching. An important element of the scientific method, taught to every schoolchild, is that the scientist must be a detached, arm's-length observer. Berman (1981: 17) notes that

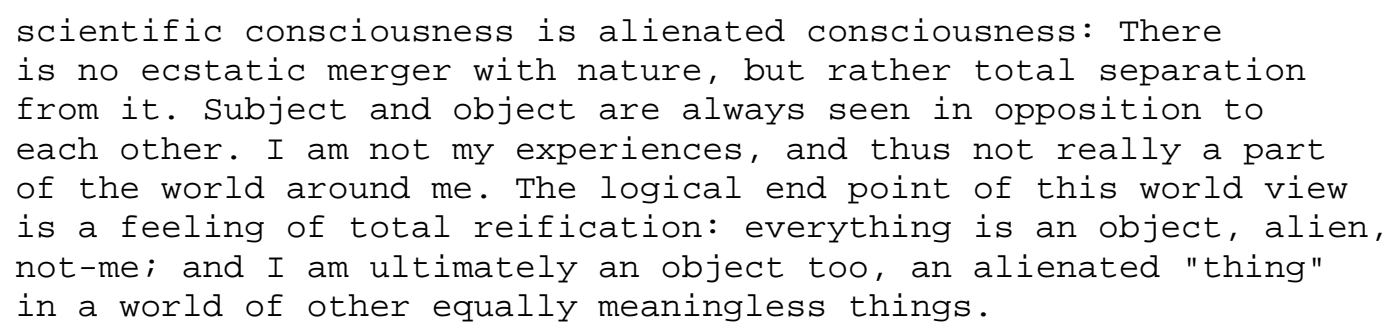

Researchers assuming perspectival observation essentially change their research question. Rather than asking what leadership is, they ask what the human experience of leadership is (Berman, 1981: 187).

Christianity has always been a religion in which subject and object are not separate and distinct. For example, Christianity offers a very personal relationship with the deity. Jesus notes in John 15:15,

I do not call you servants any longer, because a servant does not know what his master is doing. Instead, I call you friends, because I have told you everything I heard from my Father.

Moreover, there are many Biblical passages that demonstrate the oneness of the deity with the devout human: John 15:4a "Abide in me and I will abide in you." 
Perhaps the ultimate expression of "ecstatic merger with nature" is the Christian experience of "taking communion"--sharing in the body and blood of Christ. Although the scientific community will probably never appropriate a term loaded with such religious connotation, the experience of "communing" is a wonderful expression for an organizational researcher "conversing intimately; exchanging thoughts and feelings" (American Heritage Dictionary) with organizational employees. For Protestant Christians, the experience of sharing in the body and blood of Christ through the symbols of bread and wine (or juice) is one of the most sacred of experiences. For Roman Catholics, the merger is seen as more complete through the doctrine of transubstantiation, that the bread and wine are transformed miraculously at the time of consumption into the true presence of Christ. The lack of separateness is clear in passages such as Mark 14:22-24:

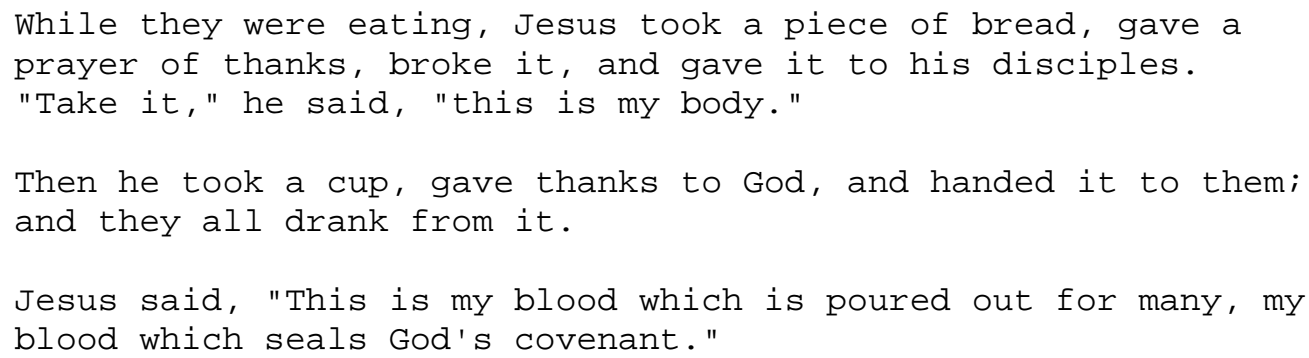

\section{CONCLUSION}

Although many writings in complexity theory would promote a further divide between complexity theory in organizations and spirituality/religion, the contention of this article is that not only are there great consistencies between them, but complexity theory can best inform organizational practice if it proceeds in ways that foster the integration of management, spirituality, and religion. The greatest threat to this integration would occur if organizational theories arose that assumed high levels of agent heterogeneity. Although such models have proven helpful in natural settings and in markets where arm's-length transactions occur, they would not accurately reflect decades of learning in organizational science and centuries of learning in the wisdom and religious traditions.

Several publications are advancing an integration of complexity theory, management, spirituality, and religion, although many of them do not explicitly use the terminology of complexity theory and/or spirituality. Several examples of these works are provided below, categorized by the philosophical assumptions discussed in this article.

\section{PARADOX (POLARITY)}

Farson, R. (1996) Management of the Absurd: Paradoxes in Leadership, New York: Simon and Schuster.

Handy, C. (1994) The Age of Paradox, Boston: Harvard Business School Press.

Wacker, W., Taylor, J., \& Means, H. B. (2000) The Visionary's Handbook: Nine Paradoxes that Will Shape the Future of Your Business, New York: HarperCollins. 


\section{HOLISM}

Greenleaf, R. K. (1977) Servant Leadership: A Journey into the Nature of Legitimate Power and Greatness, New York: Paulist Press.

Kaplan, R. S. \& Norton, D. P. (1996) The Balanced Scorecard: Translating Strategy into Action, Boston: Harvard Business School Press.

Rummler, G. A. \& Brache, A. P. (1995) Improving Performance: How to Manage the White Space on the Organization Chart, San Francisco: Jossey-Bass.

\section{INDETERMINISM}

Christensen, C. M., de Geus, A., Kirkland, J., \& Viguerie, P. (eds) (1999) Harvard Business Review on Managing Uncertainty, Boston: Harvard Business School Press.

Merry, U. (1995) Coping with Uncertainty: Insights from the New Sciences of Chaos, SelfOrganization, and Complexity, West Port, CN: Praeger.

Modis, T. (1998) Conquering Uncertainty: Understanding Corporate Cycles and Positioning Your Company to Survive the Changing Environment, New York: McGraw-Hill.

Stacey, R. D. (1992) Managing the Unknowable: Strategic Boundaries between Order and Chaos in Organizations, San Francisco: Jossey-Bass.

\section{PERSPECTIVAL}

Cooperrider, D. L., Sorensen, P. F., Whitney, D., \& Yaeger, T. F. (eds) (1999) Appreciative Inquiry: Rethinking Human Organization toward a Positive Theory of Change, San Francisco: Berrett-Koehler.

Jones, L. B. (1995) Jesus, CEO: Using Ancient Wisdom for Visionary Leadership, New York: Hyperion Press.

Zohar, D. \& Marshall, I. (2000) SQ: Connecting with Our Spiritual Intelligence, London: Bloomsbury.

Sociologists such as Sorokin (1957) have observed that one storyline of history is that of an oscillating pendulum swinging between religious and scientific extremes. He has labeled as "idealistic" the time when there has been a harmonious synthesis of faith, reason, and empiricism. Idealistic times have been rare in the last few millennia. Perhaps the recent efforts of many to focus on such a harmony will help usher in a very meaningful and productive idealistic world culture.

NOTES 
(1) Different religions and philosophies use varying terms to label the transcendent, such as supreme being, Allah, etc. The term "God" will be used throughout this article as shorthand for the transcendent.

(2) Waldrop himself is a chronicler. The researchers he reports about in the book are the ones expressing the orientation.

(3) I am indebted to editor Michael Lissack for the suggestion and genesis of this article.

(4) Peck was not a Christian when he wrote his most famous book, The Road Less Traveled. Since then, though, he has made a public statement of his new-found Christian faith (Peck, 1993a: 156-7).

(5) Studies have shown that (micro)reductionism is the modus operandi of science, having been identified as an overwhelming trend by both "specialists in the various sciences and by metascientists" (Oppenheim \& Putnam, 1991: 421). One study, for example, reported a "putative tendency among sociologists and economists to explain group behavior in terms of individual psychology, psychologists to explain individual behavior in terms of underlying physiology, physiologists to explain motor functions in terms of neurochemical composition, etc." (Trout, 1991: 389).

\section{REFERENCES}

Bateson, G. (1979) Mind and Nature: A Necessary Unity, Toronto: Bantam Books.

Bateson, G. and Bateson, M. C. (1987) Angels Fear: Towards an Epistemology of the Sacred, New York: Macmillan.

Berman, M. (1981) The Reenchantment of the World, Ithaca, NY: Cornell University Press.

Boisture, R. A. (2003) "Summary of the Commission on Children at Risk's Report, 'Hardwired to connect: The new scientific case for authoritative communities' (YMCA of the USA, Dartmouth Medical School, Institute for American Values)," Washington, DC: YMCA of the USA, http://www.ymca.net/hardwired_report/HW_companion.summ.pdf.

Daniels, D., Franz, R. S., \& Wong, K. (2000) "A classroom with a worldview: Making spiritual assumptions explicit in management education," Journal of Management Education, 24(5): 54061.

Deming, W. E. (1986) Out of the Crisis, Cambridge, MA: MIT Center for Advanced Engineering Study.

Dent, E. B. (1999) "Complexity science: A worldview shift," Emergence, 1(4): 5-19.

Dent, E. B. (forthcoming) "The scientific case for why humanists should acknowledge the existence of 'God."' 
Farson, R. (1996) Management of the Absurd: Paradoxes in Leadership, New York: Simon and Schuster.

Gell-Mann, M. (1994) The Quark and the Jaguar: Adventures in the Simple and the Complex, New York: W. H. Freeman.

Gould, S. J. (1999) Rocks of Ages: Science and Religion in the Fullness of Life, New York: Ballantine.

Green, M. B. \& Schwarz, J. H. (1984) Physics Letters, 149B(117).

Handy, C. (1994) The Age of Paradox, Boston: Harvard Business School Press.

Heisenberg, W. (1962) Physics and Philosophy: The Revolution in Modern Science, New York: Harper \& Row.

Johnson, B. (1992) Polarity Management: Identifying and Managing Unsolvable Problems, Amherst, MA: HRD Press.

Kauffman, S. (1995) At Home in the Universe: The Search for the Laws of Self-Organization and Complexity, New York: Oxford University Press.

Lewin, R. \& Regine, B. (2000) The Soul at Work: Listen ... Respond ... Let Go: Embracing Complexity Science for Business Success, New York: Simon and Schuster.

Newberg, A., D'Aquili, E., \& Rause, V. (2001) Why God Won't Go Away: Brain Science and the Biology of Belief, New York: Ballantine Books.

Oppenheim, P. \& Putnam, H. (1991) "Unity of science as a working hypothesis," in R. Boyd, P. Gasper, \& J. D. Trout (eds), The Philosophy of Science, Cambridge, MA: MIT Press.

Peacocke, A. R. (1995) "God's interaction with the world: The implications of deterministic 'chaos' and of interconnected and interdependent complexity," in R. J. Russell, N. Murphy, \& A. R. Peacocke (eds), Chaos and Complexity: Scientific Perspectives on Divine Action, Berkeley, CA: Center for Theology and the Natural Sciences.

Peck, M. S. (1987) The Different Drum: Community-Making and Peace, New York: Touchstone.

Peck, M. S. (1993a) Further along the Road Less Traveled: The Unending Journey toward Spiritual Growth, New York: Simon and Schuster.

Peck, M. S. (1993b) A World Waiting to Be Born: Rediscovering Civility, Toronto: Bantam Books.

Penrose, R. (1994) Shadows of the Mind, New York: Oxford University Press. 
Prigogine, I. \& Stengers, I. (1984) Order out of Chaos: Man's New Dialogue with Nature, Toronto: Bantam Books.

Regine, B. \& Lewin, R. (2000) "Leading at the edge: How leaders influence complex systems," Emergence, 2(2): 5-23.

Rescher, N. (2001) Paradoxes: Their Roots, Range, and Resolution, Chicago: Open Court.

Ross, H. (1996) Beyond the Cosmos: What Recent Discoveries in Astronomy and Physics Reveal about the Nature of God, Colorado Springs, CO: Navpress.

Sandelands, L. E. (2003) "The argument for God from organization studies," Journal of Management Inquiry, 12(2): 168-77.

Schwartz, P. \& Ogilvy, J. (1979) The Emergent Paradigm: Changing Patterns of Thought and Belief, Menlo Park, CA: SRI International.

Sorokin, P. (1957) Social and Cultural Dynamics, Boston: Extending Horizons Books.

Stewart, I. \& Cohen, J. (1996) Figments of Reality: The Evolution of a Curious Mind, Cambridge, UK: Cambridge University Press.

Taylor, J. H., Wolszzan, A., Damour, T., \& Weisberg, J. M. (1992) "Experimental constraints on strong-field relativistic gravity," Nature, 355: 132-6.

Trout, J. D. (1991) "Introductory essay," in R. Boyd, P. Gasper, \& J. D. Trout (eds), The Philosophy of Science, Cambridge, MA: MIT Press.

Waldrop, M. M. (1992) Complexity: The Emerging Science at the Edge of Order and Chaos, New York: Simon and Schuster.

Wilber, K. (1996) A Brief History of Everything, Boston: Shambhala.

Wilber, K. (1998) The Marriage of Sense and Soul: Integrating Science and Religion, New York: Random House. 